\title{
Biotechnological approaches for production of bioactive secondary metabolites in Nigella sativa: an up-to-date review
}

\author{
Abeer Kazmi ${ }^{1}$, Mubarak Ali Khan (iD) 1,* , Huma Ali ${ }^{2}$, Erum Dilshad ${ }^{3}$ \\ ${ }^{1}$ Department of Biotechnology, Faculty of Chemical and Life Sciences, Abdul Wali Khan University Mardan \\ (AWKUM), Mardan 23390, Pakistan \\ 2 Department of Biotechnology, Bacha Khan University, Charsadda, KP, Pakistan \\ ${ }^{3}$ Department of Bioinformatics and Biosciences, Faculty of Health and Life Sciences, Capital University of Science \\ and Technology (CUST), Islamabad Pakistan 44000
}

\begin{abstract}
Medicinal and aromatic plants and their refined natural products have gained global attraction for their therapeutic potential against many human diseases. Nigella sativa is a medicinally important plant, commonly known as Black cumin or Black seed is a dicotyledon plant of the Ranunculaceae family. It is in common use for a longer time in history as preservative and spice and has also been extensively utilized by different communities around the globe. Black cumin has been an eminent component of traditional medicine systems like Unani and Tibb, Ayurveda and Siddha. Its biological activities include antidiarrheal, analgesic, antibacterial, liver tonic, diurectic, digestive agent and to treat several skin disorders. Furthermore, the therapeutic properties also include antidiabetic, anticancer, antihypertensive, anti-inflammatory, hepatoprotective, spasmolytic and bronchodialator. This is all because of its miraculous healing power that it has been ranked as top ranked, among evidence based herbal medicines. The literature supports that the pharmacological activities of Nigella sativa are mainly because of the essential oil and its constituents particularly thymoquinone. The current review is an attempt to present a detailed literature survey regarding chemical composition, phytochemistry, therapeutic potential and biotechnological approaches to enhance the medicinal potential of this valuable plant.
\end{abstract}

\section{ARTICLE HISTORY}

Received: February 10, 2019

Revised: May 15, 2019

Accepted: June 08, 2019

\section{KEYWORDS}

Chemical composition, Medicinal significance, Nigella Sativa,

Black cumin, Phytochemistry, Therapeutic potential, Biotechnological approaches

\section{INTRODUCTION}

$N$. sativa Linn, a highly potent medicinal plant of Ranunculaceae family, is an annual flowering herb which usually grows $20-90 \mathrm{~cm}$ tall. $N$. sativa locally known as Black cumin or Black seed is natively found in the regions of Southern Europe, North Africa and Southwest Asia. Currently, it is cultivated in many countries across the globe [1,2]. N. sativa is a rabi crop and seeds

*CONTACT: Mubarak Ali Khan $₫$ makhan@awkum.edu.pk, write2mubarak@gmail.com Department of Biotechnology, Faculty of Chemical and Life Sciences, Abdul Wali Khan University Mardan (AWKUM), Mardan 23390, Pakistan

ISSN-e: 2148-6905 / (C IJSM 2019 
of this crop are sown in the month of November and harvested in March or April. Sandy and loamy soil with $\mathrm{pH} 6.85$, having $0.78 \%$ organic carbon is ideal for its cultivation $[3,4]$. The morphology of $N$. sativa flowers comprises 5 to 10 petals with color ranging from white, yellow, pink, pale blue to pale purple (Figure 1). The fruit appears like a big, inflated capsule having 3-7 united seeds containing follicles. Seeds are small, dicotyledonous and black in color with aromatic odor and bitter taste [5]. N. sativa is known with diverse names in different part of the world, such as in English: fennel flower, nutmeg flower, Roman coriander, blackseed or black caraway, black sesame; India: Assamese - kaljeera or kolajeera, Hindi/Urdu - kalaunji/ mangrail; Arabic: habbat al-barakah; French: nigelle de Crète, toute épice; Germany: Schwarzkümmel.

Due to availability of unique phytochemicals there are numerous therapeutic potentials of $N$. sativa such as anti-inflammatory, anti-analgesic, anti-stress, anticancer, antioxidant, antibacterial, antifungal, antiparasitic and antiasthmatic [1,5-8]. Plants have secondary metabolites for their defense mechanism whereas humans utilize these secondary metabolites for multiple purposes such as medicines, flavorings, and recreational drugs [9-11]. Due to phytochemicals and vast therapeutic potential, seeds of $N$. sativa got a great economic value in local and international market such as Rs. 275-500/kg in local market (Pakistan; Mingora, Dir, Peshawar, Pindi, Lahore, Gilgit). In Indian market Rs. $250-300 / \mathrm{kg}$, whereas it is put up for sale in international market for Rs. 850-1000/gm [12]. Therefore it can be one of the ideal plants for farmers to cultivate and get a good income out of it $[13,14]$. Seeds of $N$. sativa can be stored for a year in airtight bags or jars to maintain its aroma. It should be kept away from other species (condiments) as it can affect the aroma and flavor of other species [13].

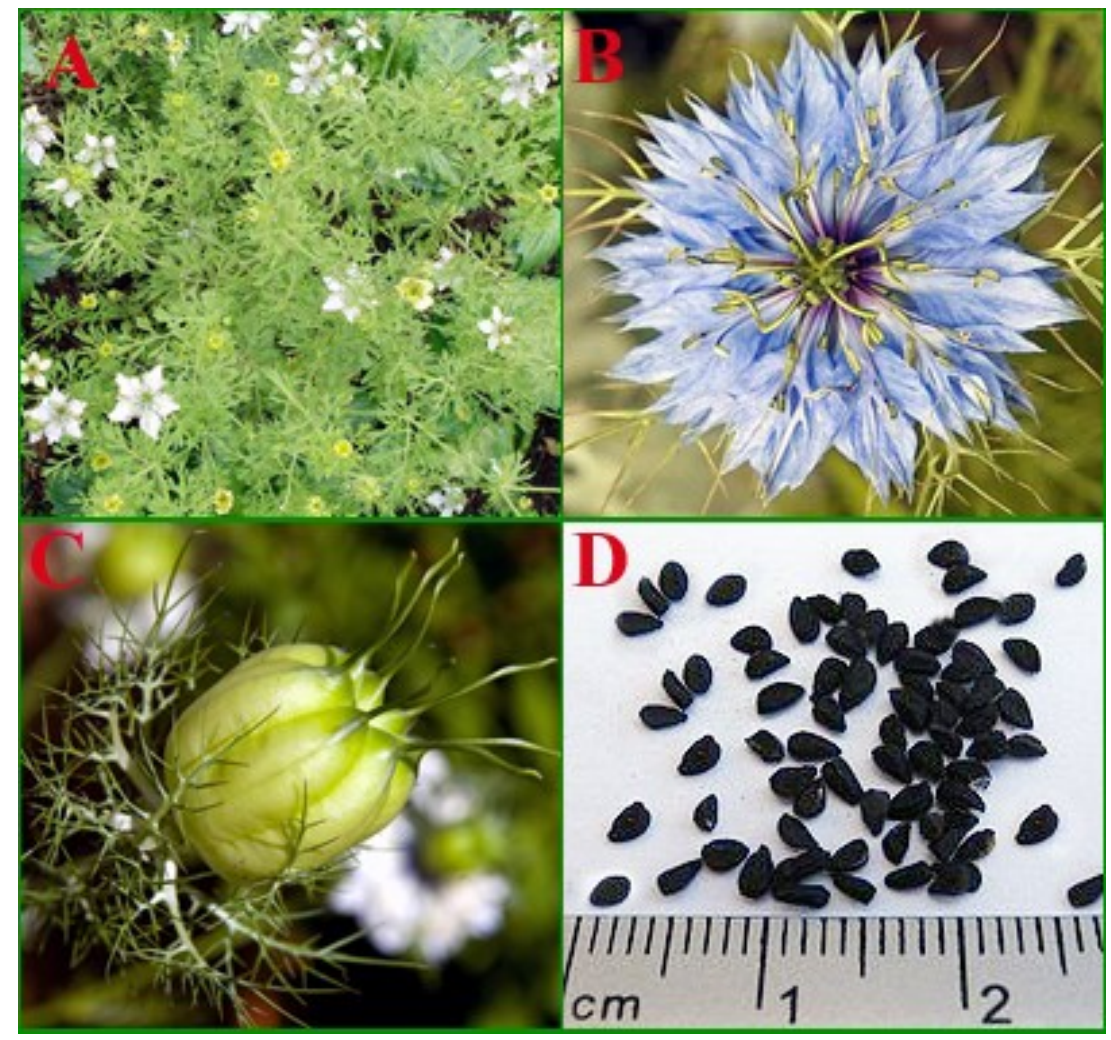

Figure 1. (A) Plant of N. sativa, (B) Flower, (C) Capsule or fruit, (D) Seeds 


\section{ACTIVE PHYTOCHEMICALS IN N. SATIVA}

The plant has undergone an extensive phytochemical analysis owing to its various medicinal properties and a general composition was found to be volatile oils (1.6\%), fixed oils (35.6-41.6\%) and proteins $(22.7 \%)$ [132]. The further composition based analysis of oils revealed that there are several important active constituents of oils like thymoquinone which comprises 30-48\%, thymohydroquinone, dithymoquinone and p-cymene constitute 7\%-15\%, carvacrol $(6 \%-12 \%), 4$ terpineol (2\%-7\%), tanethol (1\%-4\%), sesquiterpene longifolene $(1 \%-8 \%) \alpha$-pinene and thymol (Figure 2). There are found two different types of alkaloids in seeds of N. sativa i.e. isoquinoline alkaloids (nigellicimine and nigellicimine $\mathrm{N}$-oxide) and pyrazol alkaloids/indazole ring containing alkaloids (nigellidine and nigellicine). Seeds of $N$. sativa also contain water soluble pentacyclic triterpene (alpha-hederin) along with saponins [7]. Other important constituents found in the seeds include protein, fat, carbohydrates, crude fibre, vitamins and minerals like $\mathrm{Cu}, \mathrm{P}, \mathrm{Zn}$ and Fe etc [8]. Additional chemical components are nigellone, avenasterol-5-ene, avenasterol- 7-ene, campesterol, cholesterol, citrostadienol, lophenol, obtusifoliol, stigmastanol, stigmasterol-7-ene, $\beta$-amyrin, butyro- spermol, cycloartenol, 24-methylene-cycloartanol, taraxerol, tirucallol, 3-O-[ $\beta$ D xylopyranosyl $(1 \rightarrow 3)-\alpha$-L- rhamnopyranosyl $(1 \rightarrow 2)-\alpha$-L-arabino-pyranosyl]-28-O-[ $\alpha$ - Lrhamnopyranosyl $(1 \rightarrow 4)$ - $\beta$-D-glucopyranosyl $(1 \rightarrow 6)-\beta$-D- gluco-pyranosyl] hederagenin, volatile oil, fatty oil, oleic acid, esters of unsaturated fatty acids (Figure 3 ) and higher terpenoids, esters of dehydrostearic and linoleic acid, aliphatic alcohol, melanthin, melanthigenin, 3-O- [ $\beta-\mathrm{D}-$ xylopyranosyl-( $1 \rightarrow 2)$ - $\alpha$-L-rhamno- pyranosyl-( $1 \rightarrow 2)-\beta$ - D-glucopyranosyl]-11-methoxy- 16,23 dihydroxy-28-methylolean-12-enoate,stigma-5, 22-dien- 3- $\beta$-D-gluco-pyranoside, cycloart-23methyl-7, 20, 22- triene-3 $\beta, 25$-diol, nigellidine-4-O-sulfite $[10,15]$.<smiles>CC1=CC(=O)C(C(C)C)=CC1=O</smiles><smiles>Cc1cc(O)c(C(C)C)cc1O</smiles><smiles>CC(C)C1=CC(=O)[C@]2(C)C(C1=O)[C@]1(C)C(=O)C=C(C(C)C)C(=O)C21</smiles>

(D)<smiles>Cc1ccc(C(C)C)cc1O</smiles>

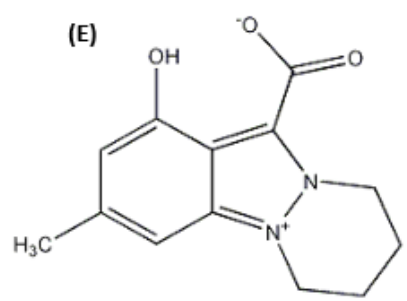

Figure 2. Structure of Thymoquinone (A), Thymohydroquinone (B), Dithymoquinone (C), Thymol (D), Nigellicine (E) 


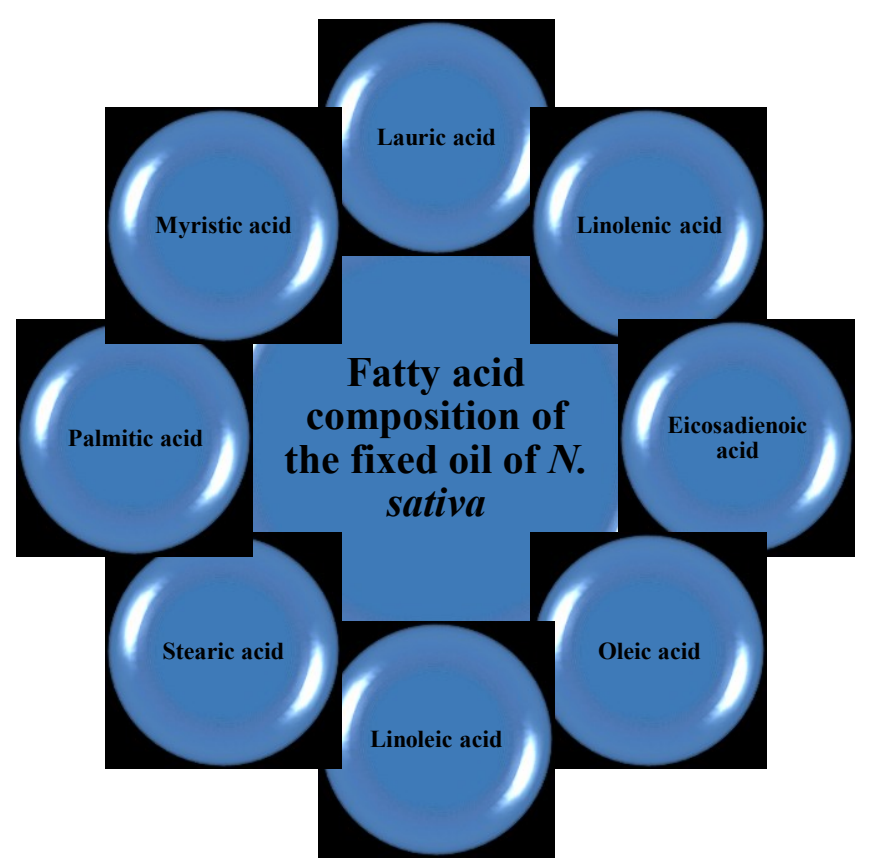

Figure 3. Fatty acid composition of the fixed oil of N. sativa

\section{MEDICINAL and PHARMACOLOGICAL APPLICATIONS}

To prevent and cure variety of diseases all over the world, seeds of $N$. sativa are used in herbal medicines. Prophet Mohammad (Peace Be Upon Him) said: "Use this Black Seed; it has a cure for every disease except death" (Sahih Bukhari). There are several ailments like skin disorders, respiratory disorders including asthma, bronchitis, disorders of joints like rheumatism and disorders of gastrointestinal track i.e. diarrhea and also hepatic one which are cured by the seeds of $N$. sativa. It gives strength to immune system and increase milk production in females [16]. Worm treatment is also reported by using the seeds and which are also helpful in the treatment of nausea. Oil of $N$. sativa has the ability to work as an antiseptic and a local anesthetic [17].

Different studies have proved that $N$. sativa and its active secondary metabolites can be effective in different pharmacological activities such as diuretic, antihypertensive, bronchodilator, gastroprotective, hepatoprotective, antidiabetic, anticancer and immunomodulatory, analgesic, antimicrobial, analgesics and anti-inflammatory, spasmolytic, renal protective and antioxidant properties, summarized in Table 1. 
Table 1. Biological Activities of N. sativa

\begin{tabular}{|c|c|c|c|c|c|}
\hline \multirow{5}{*}{\multicolumn{2}{|c|}{$\begin{array}{l}\text { Extract type/metabolite } \\
\text { Thymoquinone }\end{array}$}} & Activities/ effect & Remarks & Experimental model & References \\
\hline \multirow{14}{*}{$\begin{array}{l}\text { Nigella } \\
\text { sativa }\end{array}$} & & Antioxidant & & Wistar rat & {$[18,19]$} \\
\hline & & Antiarthritic & & & \\
\hline & & Anti hypertensive & $\begin{array}{l}\text { averted the decrease of platelet } \\
\text { numbers, prothrombotic events, } \\
\text { systolic blood pressure, } \\
\text { Leucocytosis and increased IL- } 6 \\
\text { concentration }\end{array}$ & Mice & {$[20]$} \\
\hline & & Gastroprotective & & Animal model & {$[21]$} \\
\hline & Seed oil & & & & \\
\hline & Aqueous extract of seeds & Hepatoprotective activity & & Male Wistar rats & [22] \\
\hline & Hexane extract of seeds & Prevented pregnancy & & Rats & {$[23]$} \\
\hline & Ethanolic extract of seeds & Anti-fertility activity & & Male rats & [24] \\
\hline & Seeds oil & Anti-oxytocic & $\begin{array}{l}\text { inhibited uterine smooth muscle } \\
\text { contraction }\end{array}$ & Rat and guinea pig & {$[25]$} \\
\hline & Seed ethanol extract & Antihyperglycemic & $\begin{array}{l}\text { amplified glucose-stimulated } \\
\text { insulin secretion by more than } \\
35 \% \text {, accelerated } \beta \text {-cell } \\
\text { proliferation, increased basal } \\
\text { glucose uptake by } 55 \%\end{array}$ & in vivo & {$[26]$} \\
\hline & $\begin{array}{l}\text { Seed extracts } \\
\text { Essential oil and ethyl } \\
\text { acetate extracts }\end{array}$ & Anti-cancer & & In vitro and in vivo & {$[27]$} \\
\hline & $\begin{array}{l}\text { Melanin } \\
\text { Thymoquinone }\end{array}$ & Antimicrobial & & In vitro & {$[28,29]$} \\
\hline & Ethanolic extract & Antibacterial & & & {$[30]$} \\
\hline & Ethyl ether extract & & $\begin{array}{l}\text { inhibition of Staphylococcus } \\
\text { aureus Pseudomonas }\end{array}$ & & {$[31]$} \\
\hline
\end{tabular}




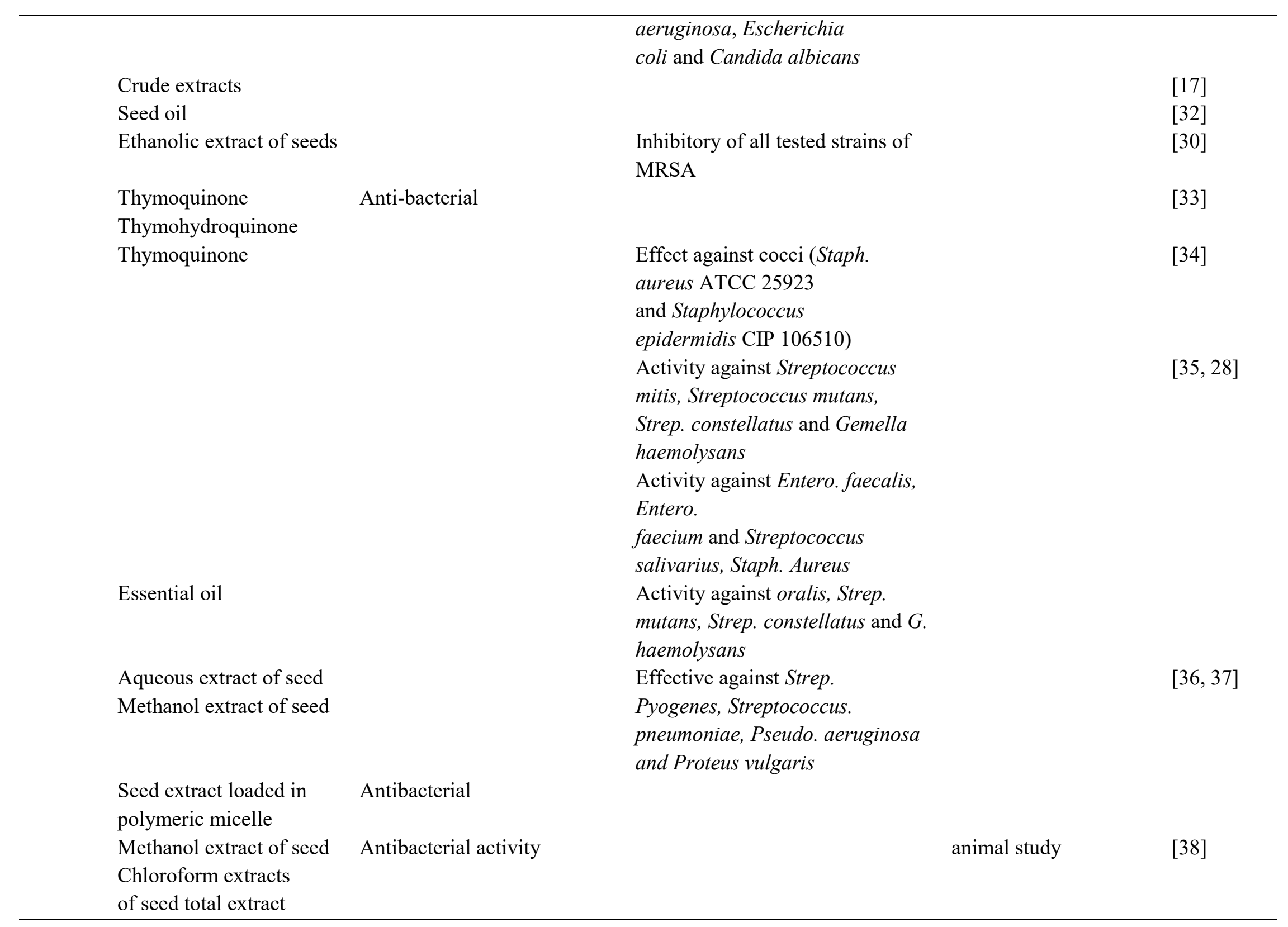




\begin{tabular}{|c|c|c|c|c|}
\hline \multicolumn{5}{|l|}{ Essential oil of seeds } \\
\hline Thymoquinone & $\begin{array}{l}\text { Antioxidant, Hepato- } \\
\text { protectant, Anti bacterial }\end{array}$ & $\begin{array}{l}\text { Prevents damage in an acute } \\
\text { pyelonephritis (PYN) caused by } \\
\text { Esch. Coli } \\
\text { protective effect in kidney tissue }\end{array}$ & rat model & [19] \\
\hline Methanol extract of seeds & Antibacterial & $\begin{array}{l}\text { effective against bacteria cause } \\
\text { mastitis }\end{array}$ & cows that have mastitis & [29] \\
\hline Seeds & Anti $H$. Pylori activity & & $\begin{array}{l}\text { patients with non-ulcer } \\
\text { dyspepsia }\end{array}$ & [39] \\
\hline $\begin{array}{l}\text { Thymoquinone } \\
\text { Ether extract of seed }\end{array}$ & Antidermatophyte effects & & In vitro & [40] \\
\hline $\begin{array}{l}\text { Dithymoquinone } \\
\text { Thymohydroquinone } \\
\text { Thymoquinone }\end{array}$ & Anti yeast activity & & & [41] \\
\hline Seed oil & Antidermatophyte effect & & & {$[42,43]$} \\
\hline Aqueous extract of seeds & Anti-fungal & $\begin{array}{l}\text { inhibitory effect against } \\
\text { candidiasis }\end{array}$ & $\begin{array}{l}\text { Candida } \\
\text { albicans infected mice }\end{array}$ & [44-46] \\
\hline \multicolumn{5}{|l|}{$\begin{array}{l}\text { Methanolic extract of } \\
\text { seeds } \\
\text { Chloroform extract of } \\
\text { seeds }\end{array}$} \\
\hline Thymoquinone & Anti-fungal & $\begin{array}{l}\text { effective against vaginal } \\
\text { candidiasis }\end{array}$ & $\begin{array}{l}\text { prednisolone induced } \\
\text { immune suppressed } \\
\text { mice }\end{array}$ & {$[47]$} \\
\hline \multirow{3}{*}{$\begin{array}{l}\text { Plant oil } \\
\text { Thymoquinone } \\
\text { Seeds } \\
\text { Oil }\end{array}$} & $\begin{array}{l}\text { Anti-schistosomal effects, } \\
\text { antioxidant effects }\end{array}$ & $\begin{array}{l}\text { improved hepatic function and the } \\
\text { immunological system }\end{array}$ & $\begin{array}{l}\text { mice infected } \\
\text { with Schistosoma } \\
\text { mansoni }\end{array}$ & [48-51] \\
\hline & Antiviral effect & & $\begin{array}{l}\text { murine cytomegalo } \\
\text { virus (MCMV) model }\end{array}$ & {$[52]$} \\
\hline & Antiviral, antioxidant activity & enhanced RBC and platelet counts & $\begin{array}{l}\text { patient with hepatitis } \mathrm{C} \\
\text { virus }(\mathrm{HCV})\end{array}$ & {$[53]$} \\
\hline
\end{tabular}




\begin{tabular}{|c|c|c|c|}
\hline Ethanolic extract & Anti-parasite activity & $\begin{array}{l}\text { children infected with } \\
\text { cestode worms }\end{array}$ & {$[54]$} \\
\hline $\begin{array}{l}\text { Methanolic extract of } \\
\text { seeds }\end{array}$ & $\begin{array}{l}\text { Antimalarial effect, } \\
\text { antioxidant effect } \\
\text { hepatoprotactent }\end{array}$ & Mice & {$[55]$} \\
\hline $\begin{array}{l}\text { Aqueous suspensions of } \\
\text { seeds } \\
\text { Oil emulsions of seeds }\end{array}$ & $\begin{array}{l}\text { Antiparasite effect, } \\
\text { anticoccidial effects }\end{array}$ & coccidiosis in rabbits & [39] \\
\hline
\end{tabular}




\subsection{Patents}

There are five different FDA (Food and Drug Administration) patents in the U.S.A. of Nigella sativa for the treatment of following diseases [56]:

1. Inhibition of cancer cell growth, Patent no - US 5,653,981, Inventor- R. D. Medenica.

2. Diabetes, No.-US 6,042,834, Inventor - Wasif Baraka.

3. Improvement of the Immune System, No.- US 5,482,711, Inventor - R. D. Medenica.

4. Viral Infections, No.- US 6,841,174, Inventor-S. I. A. Shalaby and E. M. A. H. Allah.

5. Psoriasis, No.- US 6,531,164, Inventor - H. H. R. Credé.

\subsection{Cultivation Requirements and Challenges}

$N$. sativa is a highly medicinal plant and its demand especially for its magical oil is increasing day by day. The Nigella crop takes around 140-160 days to reach to its harvesting period as it is a rabi (cool season) crop so it grows during the winter season in India. The requirements for sowing the seeds are warm weather with a temperature range of $20-25^{\circ} \mathrm{C}$ and cold weather is required for the early growth period. The seed formation also requires the warm sunny weather thus it is the main requirement for N.sativa from seed sowing to seed formation $[57,58]$. Root rot is one of the common infections of $N$. sativa which is instigated by Rhizoctonia and Fusarium. In this disease, first the leaf color turn from green to yellow and early drying of plant occurs, which significantly decreases the crop yield. No unspoiled control procedures are available for this disease. Aphids (small sap-sucking insects), larvae of armyworm Spodoptera litura and Cercospora nigellae are also involved in damaging the crop [58]. All these issues with Nigella in wild grown conditions are dragging us towards an alternate method to meet the demands and requirements of this modern era.

Therefore, in vitro cultures are attractive technique that can play a vital role in fulfilling these demands by providing metabolites within reasonable time and quantity. Plant tissue culture is a technique through which one can grow and multiply cells, tissues and organs of plants on defined solid or liquid media under contamination free and ideal conditions. Different important metabolic compounds such as alkaloids, phenols, terpenoids, vitamins and other highly medicinal compounds can easily be isolated from this technology [59].

\section{BIOTECHNOLOGICAL ASPECTS}

\subsection{Cell Culture Technology}

Plant cell culture technology is an essential tool in basic and applied research for the production of seedlings and plants and it is very important on a commercial scale. To succeed in tissue culture, medium composition is very important [60]. Hormones such as auxins, cytokinins and gibberellic acid are used to control cell growth and division can be supplemented to the growth medium at the right time which poses an important role in the formation of callus, regeneration of other plant parts or organogenesis. These hormones can also lead to increase the amount of phenolics, flavonoids and terpenoids in different cultures such as, thidiazuron (TDZ)-induced stimulated production of phenolics and flavonoids in callus and cell suspension cultures of $A$. absinthium [61, 62]. Likewise, callus cultures of $A$. absinthium displayed the maximum levels of phenolic and flavonoid content in response to combining thidiazuron (TDZ) and naphthaleneacetic acid (NAA) [63]. Artemisinin concentration was found highest in $A$. absinthium callus cultures when treated with benzyl adenine (BA; $2.0 \mathrm{mg} / \mathrm{L}$ ) [64]. Some parts of cultivated plants need auxin to produce callus while some require only cytokinin however most cultures need both. Optimal formula of medium varies depending on the species, type of genotype within the species, origin and the age of tissue culture. In most experiments in this field, culture has been conducted in base medium of Morashige and Skoog [65] at different ratios of plant hormones. 
The most important feature of callus is that, this cellular mass has the necessary potential for organogenesis, embryogenesis and complete plant production. Beside PGRs callus formation also depends on the type of the explants used. A variety of explants are used for the callus and suspension cultures, organogenesis and embryogenesis which are summarized in Figure 4.

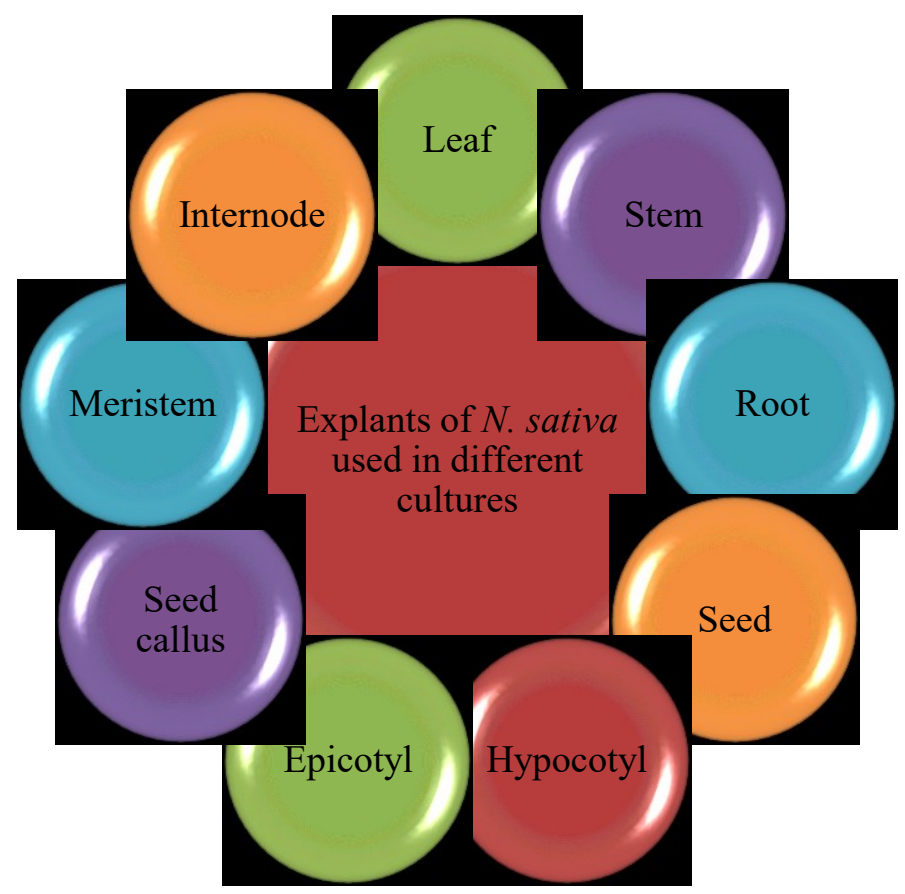

Figure 4. Explants of $N$. sativa used in different cultures

\subsection{Significance of Plant in Vitro Cultures}

There are numbers of drugs and medicines available in market for treatment of different diseases but we are still in search of novel chemical compounds which can help us in the decreasing the number of diseases and outbreaks. Therefore, we have to look towards natural resources where our synthetic drugs fail to cure us. Plants are rich with these novel chemical compounds known as phytochemicals or plant secondary metabolites, these phtochemicals are used by humans against different diseases [66]. Due to less number of availability of plant and high demand of phytochemicals, different approaches like in vitro cultures, are utilized to improve the quality and quantity of these metabolites [67]. One of the main reasons for utilization of in vitro cultures is the presence of trace amounts of these secondary plant compounds in the plants. The most likely reason for this is that different genes coordinate at different developmental stages indicating that production of useful important metabolites is growth dependent. There is also a general perception that during in vitro growth of the cells, the chemicals produced are mainly those which support the growth of the plant and production of secondary metabolites might be unnecessary or even toxic thus leading to deceased secondary metabolites production in vitro. Therefore, there is a need to optimize the in vitro growth conditions increased secondary metabolites production that would be a key to overcome this hurdle.

\subsection{Strategies to Enhance Biomass and Secondary Plant Compounds}

There are different strategies mentioned in Figure 5, which can enhance the phytochemicals in in vitro cultures. Studies have revealed that elicitation is the most effective 
method for improving and increasing the production of secondary metabolites in in vitro cultures.

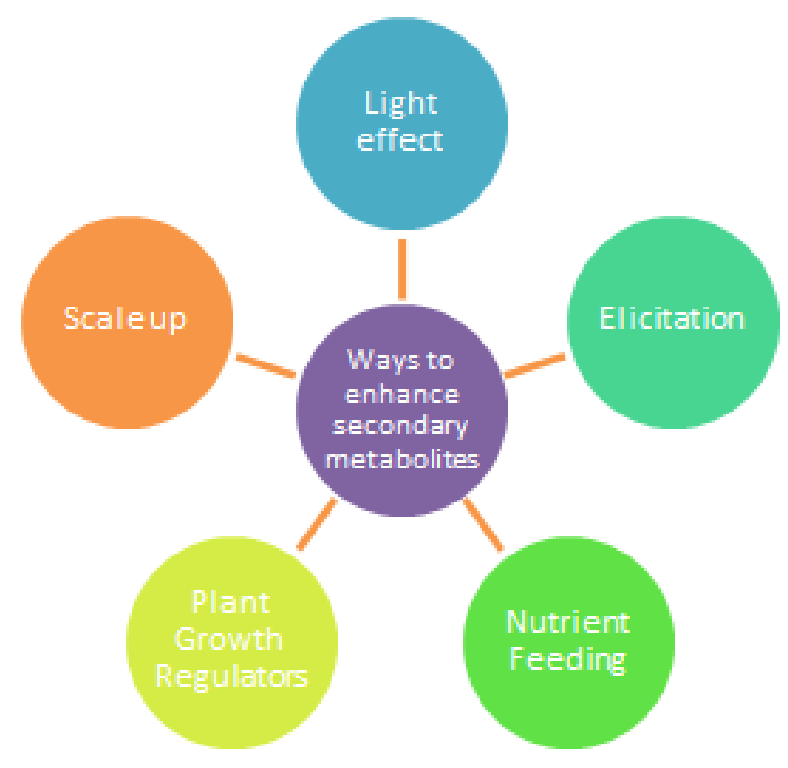

Figure 5. Strategies to enhance secondary metabolites

\subsection{Effects of PGRs}

Plant growth regulators are signaling compounds which help the plant growth and development and production of secondary metabolites [68]. Plant growth regulators (PGRs) have a significant effect on explant in plant tissue culture; they have a great impact of cell growth, differentiation, regeneration, and metabolite formation [69-71]. Different PGRs have been studied on different plants including $N$. sativa and each PGR has its own role in initiating in vitro growthand biomass formation. Datta et al. reported that 2,4-D and kinetin help in callus formation from hypocotyl segment [76]. In another study, MS media added with 2,4-D, NAA and IAA produced a significant amount of callus from leaf of Nigella sativa [75]. PGRs not only responsible for culture initiation and biomass formation, but also enhance the metabolites accumulation. Chaudhry et al. and Hoseinpanahi et al. concluded that combination of $\mathrm{Kn}+$ $\mathrm{NAA}$ and BAP + IAA enhanced terpenoid and thymol production in suspension culture of $N$. sativa [72, 73]. Al-Ani also reported that 2,4-D and $\mathrm{Kn}$ initiated callus formation from leaf explant of Nigella sativa with enhanced thymol concentration [74]. By enhancing metabolic content the antioxidant activity of culture is also increased, Further, TDZ + NAA enhanced biomass and antioxidant activity of callus of Nigella sativa [77].

\subsection{Role of Elicitors}

Elicitation is one of the most effective approachs for the enhancement and biotechnological production of secondary metabolites [134, 135]. An "elicitor" is a substance which initiates or stimulates the production of particular metabolites when applied at optimal concentrations. These compounds stimulate plant defense by promoting secondary metabolism for the protection of plant cell, to cope with the stress created by the them, as a result plant through a series of reactions such as activation of NADPH oxidase, production of reactive oxygen and nitrogen species, expression of defensive genes and secondary metabolites production [136-139]. Elicitors may be abiotic such as metal ions and inorganic compounds, or biotic from fungi, bacteria, viruses or herbivores, plant cell wall components [68]. Jasmonic acid (JA) is naturally synthesized inside plant and is responsible for different functions along with activation of production of secondary metabolites, therefore different mediators can be used to activate JA pathway $[78,79]$. In several studies PGRs stimulated the production of 
callus, organogenesis, phytochemicals which were further enhanced by the elicitors in many medicinal plants. GA3 enhanced artemisinin accumulation in hairy root cultures and shoot culture of A. annua [80, 81, 83-86] and A. dubia [82]. Similarly, Salicyclic acid (SA), AgNPs, MeJ, SPD and Chitosan enhanced stevioside biosynthesis in various cultures of Stevia [140143]. A variety of elicitors have been used in different studies to initiate cultures of $N$. sativa with higher production of secondary metabolites. Casein hydrolysate promoted callus formation and embryogenesis with enhance biomass of $N$. sativa $[87,107]$. In another study, SA enhanced the physiological parameters and also produced healthy biomass of Callus in N. sativa [88]. Increase in levels of monodesmosidic triterpene saponins $\alpha$-hederin and kalopanaxsaponin I (KsI) in the leaves of Nigella sativa were observed when treated with methyl jasmonate (MeJA) [110], GA3 enhanced germination rate of N. sativa [89], $\mathrm{AgNO}_{3}$ and SA increased secondary metabolites (fatty acids and essential oil) in callus culture [90], Nano-silver and yeast extract increased total phenol and flavonoids in N. sativa [91] (Table 2).

\subsection{Light Effect}

Light is a basic requirement for majority of plants for their growth and development and production of primary, secondary metabolites $[92,93]$. Light in Plant tissue culture can play a very major part, it is a type of physical elicitation, fluctuation of intensity and color of light can produce some sort of stress in plant which may lead to initiate culture and also stimulate the production of phytochemicals. Light has stimulated the production of protopine in suspension cultures of Fumaria, [94] phenolics and flavonoids in callus cultures of Stevia rebaudiana, [95] caffeic acid derivatives in hairy root cultures of Echinacea purpurea, [93] phenolic acids in in vitro cultured Ruta graveolens and Ruta graveolens divaricata [96]. Several reports are available on light stimulated cultures of $N$. sativa. Complete dark helped in callus initiation from seeds [97], leaf explants [98], and stem of $N$. sativa [99], Somatic embryo formation was promoted when explants of $N$. sativa were kept in dark [98]. In another study, controlled dark conditions stimulated Melanin production in suspension culture of $N$. sativa [115] (Table 2).

\subsection{Plant Cell Cultures Strategies for Phytochemical Production}

For evaluation of biomass kinetics, optimize conditions for production of highly medicinal and important secondary metabolites, Cell suspension cultures play a very central role [100]. The factors making cell suspension cultures suitable for the analysis of complex physiological processes include the homogeneous nature of cell population, the availability of material in bulk, accelerated growth of cells and conditions reproducibility [101]. Some recent examples of medicinal secondary metabolites in suspension cultures include zerumbone production in Zingiber zerumbet, [102] ursolic acid production in Eriobotrya japonica, [103] lutein and tocopherol in carrot, [104] rosmarinic acid in Satureja khuzistanica [105] and taxane in Taxus chinensis [106], enhanced terpenoid and thymol production in N. sativa [72]. Al-Ani reported that from callus culture of $N$. sativa higher thymol concentration was extracted [74]. Enhanced biomass and antioxidant activity showed by the Cotyledon derived callus culture of Nigella sativa [77]. Enhanced Thymoquinone concentration was also extracted from callus culture of Nigella sativa [133]. 
Int. J. Sec. Metabolite, Vol. 6, No. 2, (2019) pp. 172-195

Table 2. Strategies used to enhance Secondary metabolites (SMs) in various cultures of Nigella sativa.

\begin{tabular}{|c|c|c|c|c|c|c|}
\hline Specie & Explant & Culture & Medium/ PGRs & Elicitor treatments & Effect on sms & References \\
\hline \multirow{18}{*}{$\begin{array}{l}\text { Nigella } \\
\text { sativa }\end{array}$} & Epicotyls & Suspension culture & $\mathrm{Kn}(2 \mathrm{mg} / \mathrm{L})+$ & & Enhanced Terpenoid and & {$[72]$} \\
\hline & & & NAA ( $1 \mathrm{mg} / \mathrm{L})$ and & & Thymol production & \\
\hline & & & $\mathrm{BAP}(2 \mathrm{mg} / \mathrm{L})+$ & & & \\
\hline & & & IAA $(1 \mathrm{mg} / \mathrm{L})$ & & & \\
\hline & Leaf & Callus Culture & $2,4-\mathrm{D}(1 \mathrm{mg} / \mathrm{L})$ and & & Enhanced thymoquinone & {$[133]$} \\
\hline & & & kinetin $(2.15 \mathrm{mg} / \mathrm{L})$ & & & \\
\hline & Leaf & Embryogenesis & IAA $(0.5 \mathrm{mg} / \mathrm{L})$ & casein hydrolysate & & {$[107]$} \\
\hline & Hypocotyl & Callus culture & NAA $(1 \mathrm{mg} / \mathrm{L})$ & & & {$[108]$} \\
\hline & Internode and & Micropropagation through & BA, NAA & SA & & {$[88]$} \\
\hline & hypocotyls & Callus culture & & & & \\
\hline & Hypocotyledon, root & Callus Culture & BAP and 2,4-D & $\begin{array}{l}\text { yeast extract, Silver } \\
\text { nanoparticle }\end{array}$ & $\begin{array}{l}\text { Higher production of } \\
\text { phenolic and flavonoids }\end{array}$ & {$[91]$} \\
\hline & Seed, cotyledon & $\begin{array}{l}\text { Seed germination, Callus } \\
\text { culture }\end{array}$ & $\begin{array}{l}\text { Thidiazuron (TDZ) } \\
+ \text { (NAA) }\end{array}$ & $\begin{array}{l}\text { Gibberellic acid } \\
\text { (GA3) }\end{array}$ & $\begin{array}{l}\text { Higher production of } \\
\text { phenolics and flavanoids }\end{array}$ & {$[77]$} \\
\hline & Leaf & $\begin{array}{l}\text { Regeneration through Callus } \\
\text { culture }\end{array}$ & NAA, BAP, IBA & & & {$[73]$} \\
\hline & Meristem & $\begin{array}{l}\text { Regeneration through Callus } \\
\text { culture }\end{array}$ & $\mathrm{BAP}+\mathrm{NAA}$ & & & [109] \\
\hline & Callus & Suspension Culture & $\mathrm{Kn}+\mathrm{NAA}$ & casein hydrolysate & & {$[87]$} \\
\hline & & Hydroponic culture & $\begin{array}{l}\text { Hoagland liquid } \\
\text { medium }\end{array}$ & $\begin{array}{l}\text { Methyl jasmonate } \\
\text { (MeJA) }\end{array}$ & $\begin{array}{l}\text { Higher levels of the } \\
\text { monodesmosidic } \\
\text { triterpene saponins } \alpha- \\
\text { hederin and } \\
\text { kalopanaxsaponin I (KsI) }\end{array}$ & {$[110]$} \\
\hline & Hypocotyl segment & Callus culture & $\begin{array}{l}2,4-\mathrm{D}(2 \mathrm{mg} / \mathrm{L}) \text { and } \\
\text { kinetin }(1 \mathrm{mg} / \mathrm{L})\end{array}$ & & & {$[76]$} \\
\hline & Leaf & Callus culture & $\begin{array}{l}2,4-\mathrm{D}(1 \mathrm{mg} / \mathrm{L}) \text { and } \\
\mathrm{Kn}(1.5 \mathrm{mg} / \mathrm{L})\end{array}$ & & Enhanced thymol & {$[74]$} \\
\hline
\end{tabular}




\begin{tabular}{|c|c|c|c|c|c|}
\hline Leaf, stem, seed & Callus culture & IAA, NAA, Kinetin & $\begin{array}{l}\text { Dark incubation of } \\
\text { seeds }\end{array}$ & & {$[97]$} \\
\hline Excised hypocotyls & callus culture & $\begin{array}{l}\text { IAA, NAA, IBA, } \\
\text { and 2,4-D }\end{array}$ & & & [111] \\
\hline Leaf & callus culture & & $\mathrm{AgNO} 3$ and $\mathrm{SA}$ & $\begin{array}{l}\text { Increased fatty acids and } \\
\text { essential oil content }\end{array}$ & {$[90]$} \\
\hline $\begin{array}{l}\text { Root and sprout } \\
\text { segments }\end{array}$ & Callus Culture & $\begin{array}{l}\text { benzyl aminopurine } \\
\text { and indole acetic } \\
\text { acid. }\end{array}$ & MeJA & More feruloylquinic acid & {$[112]$} \\
\hline Leaf, stem, root & somatic embryos & $\begin{array}{l}\text { Kinetin. 2,4-D, } \\
\text { NAA }\end{array}$ & $\begin{array}{l}\text { Cultures incubation in } \\
\text { complete dark }\end{array}$ & & {$[98]$} \\
\hline Root, stem, leaf & Callus Culture & $\begin{array}{l}\text { NAA, Coconut } \\
\text { milk, IAA }\end{array}$ & & & [113] \\
\hline Stem & Callus culture & Kinetin, NAA & Complete Dark & & {$[99]$} \\
\hline Leaf & Callus culture & $2,4-\mathrm{D}$ & Deltamethrine & Increase in protein content & {$[114]$} \\
\hline Leaf, stem, root & Callus and suspension cultures & $\begin{array}{l}\text { Kinetin, 2,4-D, } \\
\text { NAA }\end{array}$ & $\begin{array}{l}\text { controlled dark } \\
\text { conditions }\end{array}$ & Melanin production & {$[115]$} \\
\hline Seed & Callus culture & $\begin{array}{l}\text { 2,4-D, kinetin } \\
\text { coconut milk }\end{array}$ & $\begin{array}{l}\text { yeast } \\
\text { extract }\end{array}$ & $\begin{array}{l}\text { Variation in chromosome } \\
\text { number }\end{array}$ & {$[116]$} \\
\hline Leaf & $\begin{array}{l}\text { Organogenesis through Callus } \\
\text { culture }\end{array}$ & $\begin{array}{l}\text { 2,4-D + kinetin (6- } \\
\text { furfuryl amino } \\
\text { purine), coconut } \\
\text { milk, IAA or NAA }\end{array}$ & casein hydrolysate & & {$[117]$} \\
\hline Hypocotyl & $\begin{array}{l}\text { Callus culture, Suspension } \\
\text { culture }\end{array}$ & $\begin{array}{l}\text { kinetin, 6-BA, } \\
\text { 2,4-D, NAA, IBA, }\end{array}$ & & & [118] \\
\hline Seed & $\begin{array}{l}\text { Callus culture, Suspension } \\
\text { culture }\end{array}$ & $\begin{array}{l}2,4-\mathrm{D}(2 \mathrm{mg} / \mathrm{L}) \text { and } \\
\text { kinetin }\end{array}$ & & Protoplast isolation & [119] \\
\hline Leaf & Callus Culture & $\begin{array}{l}\text { kinetin, } \\
\text { 2,4-D, NAA }\end{array}$ & & More Thymol production & {$[120]$} \\
\hline Seed callus & $\begin{array}{l}\text { Callus culture, suspension } \\
\text { culture, Biotransformation }\end{array}$ & Kinetin + IAA & $\begin{array}{l}\text { limonene dissolved in } \\
\text { DMSO }\end{array}$ & $\begin{array}{l}\text { Production of carveol, } \\
\text { limonene-1,2-diol , p- }\end{array}$ & {$[121]$} \\
\hline
\end{tabular}


Int. J. Sec. Metabolite, Vol. 6, No. 2, (2019) pp. 172-195

\begin{tabular}{|c|c|c|c|c|c|}
\hline & & & & $\begin{array}{l}\text { mentha-2,8-diene-1-ol- } \\
\text { trans and carvone }\end{array}$ & \\
\hline Stem & Callus culture & $2,4-\mathrm{D}$ or PDA & & $\begin{array}{l}\text { Activity of GDH was } \\
\text { increased }\end{array}$ & [122] \\
\hline Stem & Callus, suspension Culture & 2,4-D and Kin & Sulphanilamide & $\begin{array}{l}\text { Enhanced thymol } \\
\text { production }\end{array}$ & [123] \\
\hline Seed, stem & Callus culture & $2,4-\mathrm{D}$ & $\begin{array}{l}\text { thymidine } \\
\text { phosphorlase }\end{array}$ & $\begin{array}{l}\text { Increase in the cellular } \\
\text { contents of proteins, } \\
\text { nucleic acids and folate } \\
\text { extract }\end{array}$ & [124] \\
\hline $\begin{array}{l}\text { Root, hypocotylodon } \\
\text { and leaf }\end{array}$ & Callus culture & 2,4-D, BAP & $\begin{array}{l}\text { yeast extract and nano } \\
\text { silver }\end{array}$ & More flavonoid content & [125] \\
\hline
\end{tabular}




\section{NIGELLA SATIVA IN NANOTECHNOLOGY}

Plants have majority of phytochemicals such as phenols, acids, tannins, steroids, terpenes etc which can be utilize in synthesis of nanoparticles (Green synthesis). Plants derived nanoparticles are environment friendly with low cost and can be used in majority of therapeutic and pharmacological applications such as antibacterial, antitumor, and can also be used as biosensor. Seed extract of $N$. sativa and AgNO3 resulted in the formation of silver nanorods, which showed antidiabetic property, in vitro [126]. Silver nanorods were also prepared from the leaf extract of $N$. sativa [127]. Gold nanoparticles AuNPs have also been prepared from seed extract of $N$. sativa and aqueous chloroauric acid solution [128]. Plant extracts of Nigella sativa, Dioscorea alata was used to produce phytochemical capped Silver nanoparticles, thymoquinone, dioscorin and ferulic acid worked as capping agents [129]. Encapsulation of TQ into nanoparticles enhances its anti-proliferative, anti-inflammatory effects and can be used in variety of biomedical applications [130] Silver nanoparticles prepared from essential oil of $N$. sativa, showed inhibitory activity against pathogenic Vibrio harveyi and $V$. parahaemolyticus [131].

\section{CONCLUSIONS}

Nigella sativa has shown substantial therapeutic effects on several biological systems. The volatile oil as well as organic and aqueous fractions of the seeds has been proven to possess beneficial effects in terms of medicinal significance. The presence of active proteins and lipid soluble elements provide the clue to the several mechanisms of actions behind therapeutic potential. Although, the Nigella sativa has become the topic of research worldwide, still there is lot of room to be explored regarding this phytotherapeutic source and no doubt clinical trials need to be done to validate the therapeutic efficacy of the plant.

\section{Conflicts of Interest}

All the authors declared that there is no conflict of interest with regards to any part of the manuscript.

\section{ORCID}

\section{Mubarak Ali Khan (iD https://orcid.org/0000-0002-7994-4244}

\section{REFERENCES}

[1] Khare, C.P. (2004). Encyclopedia of Indian medicinal plants. NewYork Springes-Verlag Berlin Heidelberg.

[2] Paarakh, P. M. (2010). Nigella sativa Linn.- A comprehensive review. Indian J. Nat. Prod. 1, 409- 429.

[3] Mandal, A., Datta, A. K., Bhattacharya, A. (2011). Evaluation of pollen and productive parameters, their interrelationship and clustering of eight Corchorus spp. (Tiliaceae). Nucleus 54, DOI 10.1007/s13237-011-0044

[4] Datta, A. K., Saha, A. (2003). Cytomorphological Studies and Seed Protein Characterization of Nigella sativa L. and Nigella damascena L. Cytologia 68, 51-60.

[5] Warrier, P.K., Nambiar, V.P.K., Ramankutty. (2004). Indian medicinal plants-a compendium of 500 species. Chennai Orient Longman Pvt Ltd, 139-142.

[6] Goreja, W.G. (2003). Black seed nature's miracle remedy. New York, NY 7 Amazing Herbs Press.

[7] Al-Jassir, M.S. (1992). Chemical composition and microflora of black cumin (Nigella sativa L.) seeds growing in Saudi Arabia. Food Chemistry, 45, 239-242. 
[8] Cheikh-Rouhou, S., Besbes, S., Lognay, G., Blecker, C., Deroanne, C., Attia, H. (2008). Sterol composition of black cumin (Nigella sativa L.) and Aleppo pine (Pinus halpensis Mill.) seed oils. Journal of Food Composition and Analysis, 21(2), 162-168.

[9] Bourgou, S., Ksouri, R., Bellila, A., Skandrani, I., Falleh, H., Marzouk, B. (2008). Phenolic composition and biological activities of Tunisian Nigella sativa L. shoots and roots. Comptes Rendus Biologies, 331(1), 48-55.

[10] Nickavar, B., Mojab, F., Javidnia, K., Amoli, M.A. (2003). Chemical composition of the fixed and volatile oils of Nigella sativa L. from Iran. Z Naturforsch, 58(9-10), 629-631.

[11] Katare, D.P., Aeri, V., Bora, M. (2009). Secondary metabolites and metabolic engineering. Journal of Cell Tissue Research, 9(3), 2027-2036.

[12] Bharat, B.A., Ajaikumar, B.K. (2009). Molecular Targets And Therapeutic Uses Of Spices: Modern Uses For Ancient Medicine. Woprld Scientific Publishing Company, 259264.

[13] Mandal, A., Datta, A.K., Bhattacharya, A. (2011). Evaluation of pollen and productive parameters, their interrelationship and clustering of eight Corchorus spp. (Tiliaceae). Nucleus, 54, DOI 10.1007/s13237-011-0044-y

[14] Sharma, P.C., Yelne, M.B., Dennis, T.J. (2005). Database on Medicinal Plants Used in Ayurveda, CCRAS, New Delhi, 6, 420-440.

[15] Mehta, B.K., Mehta, P., Gupta, M. (2009). A new naturally acetylated saponin from Nigella sativa. Carbohydrate, 344, 149-151.

[16] Al-Ali, A., Alkhawajah, A.A., Randhawa, M.A., Shaikh, N.A. (2008). Oral and intraperitoneal LD50 of thymoquinone, an active principle of Nigella sativa, in mice and rats. Journal of Ayub Medical College Abbottabad, 20(2), 25-27.

[17] Morsi, N.M. (2000). Antimicrobial effect of crude extracts of Nigella sativa on multiple antibiotics-resistant bacteria. Acta Microbiol, 49, 63-74.

[18] Umar, S., Zargan, J., Umar, K., Ahmad, S., Katiyar, C.K., Khan, H.A. (2012). Modulation of the oxidative stress and inflammatory cytokine response by thymoquinone in the collagen induced arthritis in Wistar rats. Chemico Biological Interaction, 197(1), 40-46.

[19] Evirgen, O., Gokçe, A., Ozturk, O.H., Nacar, E., Onlen, Y., Ozer, B. (2011). Effect of thymoquinone on oxidative stress in Escherichia coli-Induced Pyelonephritis in Rats. Current Therapeutic Research, Clinical and Experimental, 72, 204-215.

[20] Nemmar, A., Al-Salam, S., Zia, S., Marzouqi, F., Al-Dhaheri, A., Subramaniyan, D. (2011). Contrasting actions of diesel exhaust particles on the pulmonary and cardiovascular systems and the effects of thymoquinone. British Journal of Pharmacology, 164(7), 1871-1882.

[21] El-Abhar, H.S., Abdallah, D.M., Saleh, S. (2003). Gastroprotective activity of Nigella sativa oil and its constituent, thymoquinone, against gastric mucosal injury induced by ischaemia/reperfusion in rats. Journal of Ethnopharmacology, 84(2-3), 251-8.

[22] Mohideen, S., Ilavarasan, R., Sasikala, E.R., Thirumalai, K.R. (2003). Hepatoprotective Activity of Nigella sativa Linn. Indian journal of pharmaceutical sciences, 65(5), 550551.

[23] Keshri, G., Singh, M.M., Lakshmi, V., Kamboj, V.P. (1995). Post-coital contraceptive efficacy of the seeds of Nigella sativa in rats. Indian Journal of Physiology and Pharmacology, 39(1), 59-62.

[24] Agarwal, C., Narula, A., Vyas, D.K., Jacob, D. (1990). Effect of seeds of kalaunji on fertility and sialic acid content of the reproductive organs of male rat. Geo Bios, 17, 269272.

[25] Aqel, M., Shaheen, R. (1996). Effects of the volatile oil of Nigella sativa seeds on the uterine smooth muscle of rat and guinea pig. Journal of Ethnopharmacology, 52(1), 2326. 
[26] Zaoui, A., Cherrah, Y., Mahassini, N., Alaoui, K., Amarouch, H., Hassar, M. (2002). Acute and chronic toxicity of Nigella sativa fixed oil. Phytomedicine, 9(1), 69-74.

[27] Mbarek, A., Elabbadi, N., Bensalah, M., Gamouh, A., Aboufatima, Benharref. (2007). Anti-tumor properties of blackseed (Nigella sativa L.) extracts. Brazilian Journal of Medical and Biological Research, 40, 839-847.

[28] Bakathir, H.A., Abbas, N.A. (2011). Detection of the antibacterial effect of Nigella sativa ground seeds with water. African Journal of Traditional Complementry and Alternative Medicines, 8, 159-164.

[29] Monika, T., Sasikala, P., Vijaya, Bhaskara, Reddy, M. (2013). A investigational of antibacterial activities of Nigella sativa on mastaitis in dairy crossbred cows. International Journal of Advanced Scientific and technical Research, 3, 263-272.

[30] Hannan, A., Saleem, S., Chaudhary, S., Barkaat, M., Arshad, M.U. (2008). Anti-bacterial activity of Nigella sativa against clinical isolates of methicillin resistant Staphylococcus aureus. Journal of Ayub Medical College Abbottabad, 20, 72-74.

[31] Hanafy, M.S., Hatem, M.E. (1991). Studies on the antimicrobial activity of Nigella sativa seed (black cumin) Journal of Ethnopharmacology, 34, 275-278.

[32] Nair, M.K.M,, Vasudevan, P., Venkitanarayanan, K. (2005). Antibacterial effect of black seed oil on Listeria monocytogenes. Food Control, 16, 395-398.

[33] Salem, E.M., Yar, T., Bamosa, A.O., Al-Quorain, A., Yasawy, M.I., Alsulaiman, R.M. (2010). Comparative study of Nigella sativa and triple therapy in eradication of Helicobacter Pylori in patients with non-ulcer dyspepsia. Saudi Journal of Gastroenterology, 16(3), 207-214.

[34] Chaieb, K., Kouidhi, B., Jrah, H., Mahdouani, K., Bakhrouf, A. (2011). Antibacterial activity of Thymoquinone, an active principle of Nigella sativa and its potency to prevent bacterial biofilm formation. BMC Complementry and Alternative Medicines, 11, 1-6.

[35] Harzallah, H.J., Kouidhi, B., Flamini, G., Bakhrouf, A., Mahjoub, T. (2011). Chemical composition, antimicrobial potential against cariogenic bacteria and cytotoxic activity of Tunisian Nigella sativa essential oil and thymoquinone. Food Chemistry, 129, 14691474.

[36] Hasan, N.A., Nawahwi, M.Z., Malek, H.A. (2013). Anti microbial activity of Nigella sativa seed extract. Sains Malaysiana, 42, 143-147.

[37] Deepak, S.S., Sikender, M., Garg, V., Samim, M. (2011). Entrapment of seed extract of Nigella sativa into thermosensitive (NIPAAm-Co-VP) co-polymeric micelles and its antibacterial activity. International Journal of Pharmaceutical Science and Drug Research, 3, 246-252.

[38] Hosseinzadeh, H., Fazly-Bazzaz, B.S., Motevaly-Haghi, M. (2007). Antibacterial activity of total extracts and essential oil of Nigella sativa L. seeds in mice. Pharmacology online, 2, 429-435.

[39] Baghdadi, H.B., Al-Mathal, E.M. (2011). Anti-coccidial activity of Nigella sativa L. Journal of Food and Agricultural Enviroment, 9, 10-17.

[40] Aljabre, S.H., Randhawa, M.A., Akhtar, N., Alakloby, O.M., Alqurashi, A.M., Aldossary, A. (2005). Antidermatophyte activity of ether extract of Nigella sativa and its active principle, thymoquinone. Journal of Ethnopharmacology, 101, 116-119.

[41] Rogozhin, E.A., Oshchepkova, Y.I., Odintsova, T.I., Khadeeva, N.V., Veshkurova, O.N., Egorov, T.A. (2011). Novel antifungal defensins from Nigella sativa L. seeds. Plant Physiology and Biochemistry, 49(2), 131-137.

[42] El-Nagerabia, S.A., Al-Bahryb, S.N., Elshafieb, A.E., AlHilalib, S. (2012). Effect of Hibiscus sabdariffa extract and Nigella sativa oil on the growth and aflatoxin B1 production of Aspergillus flavus and Aspergillus parasiticus strains. Food Control, 25, $59-63$. 
[43] Sunita, M., Meenakshi, S.H. (2013). Chemical composition and antidermatophytic activity of Nigella sativaessential oil. African Journal of Pharmacy and Pharmacology, 7, 12861292.

[44] Bita, A., Rosu, A.F., Calina, D., Rosu, L., Zlatian, O., Dindere, C. (2012). An alternative treatment for Candida infections with Nigella sativa extracts. Eurpean Journal of Hospital Pharmacy, 19, 162.

[45] Fierro, I.M., Barja-Fidalgo, C., Cunha, F.Q., Ferreira, S.H. (1996). The involvement of nitric oxide in the anti-Candida albicans activity of rat neutrophils. Immunology, 89, 295300.

[46] Khan, M.A., Ashfaq, M.K., Zuberi, H.S., Mahmood, M.S., Gilani, A.H. (2003). The in vivo antifungal activity of the aqueous extract from Nigella sativa seeds. Phytotherapy Research, 17, 183-186.

[47] Abdel-Azeiz, A.Z., Saad, A.H., Darweesh, M.F. (2013). Efficacy of thymoquinone against vaginal candidiasis in prednisolone-induced immunosuppressed mice. Journal of American Science, 9, 155-159.

[48] Mahmoud, M.R., El-Abhar, H.S., Saleh, S. (2002). The effect of Nigella sativa oil against the liver damage induced by Schistosoma mansoni infection in mice. Journal of Ethnopharmacology, 79, 1-11.

[49] Aboul-Ela, E.I. (2002). Cytogenetic studies on Nigella sativa seeds extract and thymoquinone on mouse cells infected with schistosomiasis using karyotyping. Mutation Research, 516, 11-17.

[50] Mohamed, A.M., Metwally, N.M., Mahmoud, S.S. (2005) Sativa seeds against Schistosoma mansoni different stages. Memórias do Instituto Oswaldo Cruz, 100, 05-211.

[51] Shenawy, E.1., Nahla, S., Soliman, M.F., Reyad, S.I. (2008). The effect of antioxidant properties of aqueous garlic extract and Nigella sativa as anti- schistosomiasis agents in mice. Revista do Instituto de Medicina Tropical de São Paulo, 50, 29-36.

[52] Salem, M.L., Hossain, M.S. (2000). Protective effect of black seed oil from Nigella sativa against murine cytomegalovirus infection. International Journal of Immunopharmacology, 22, 729-740.

[53] Barakat, E.M.E.l., Wakeel, L.M., Hagag, R.S. (2013). Effects of Nigella sativa on outcome of hepatitis C in Egypt. World Journal of Gastroenterology, 19, 2529-2536.

[54] Akhtar, M.S., Riffat, S. (1991). Field trial of Saussurea lappa roots against nematodes and Nigella sativa seeds against cestodes in children. Journal of Pakistan Medical Association, 41, 185-187.

[55] Okeola, V.O., Adaramoye, O.A., Nneji, C.M., Falade, C.O., Farombi, E.O., Ademowo, O.G. (2011). Antimalarial and antioxidant activities of methanolic extract of Nigella sativa seeds (black cumin) in mice infected with Plasmodium yoelli nigeriensis. Parasitology Research, 108, 1507-1512.

[56] Datta, A.K., Saha, A., Bhattacharya, A., Mandal, A., Paul, R., Sengupta, S. (2012). Black cumin (Nigella sativa L.) - a review. Journal of Plant Development Sciences, 4 (1), 1-43. 2012

[57] Pruthi, J.S. (2001). Minor Spices and Condiments. ICAR, New Delhi, 1-782.

[58] Malhotra, S.K. (2002). Nigella cultivation practices (in Hindi). NRCSS, Ajmer. Extension Folder No. 7, 1-4.

[59] Shengwei, Z., Jingsam, S. (2000). Rapid plant regeneration from cotton Gossypium hirsutum L. Chinese Science Bulletin, 45(19), 1772-1773.

[60] Thorpe, T. A. (1990). The current status of plant tissue culture. Plant Tissue Culture, Applications and Limitations (Bhojwani, S. S., ed.), Elsevier, Amsterdam, 1-33. 
[61] Ali, M., Abbasi, B.H., Ihsan-ul-Haq. (2013). Production of commercially important secondary metabolites and antioxidant activity in cell suspension cultures of Artemisia absinthium L. Industrial Crops Production, 49, 400-406.

[62] Ali, M., Abbasi, B.H. (2014). Thidiazuron-induced changes in biomass parameters, total phenolic content, and antioxidant activity in callus cultures of Artemisia absinthium L. Applied Biochemistry and Biotechnology, 172, 2363-2376.

[63] Tariq, U., Ali, M., Abbasi, B.H. (2014). Morphogenic and biochemical variations under different spectral lights in callus cultures of Artemisia absinthium L. Journal of Photochemistry and Photobiology B, 130, 264-271.

[64] Zia, M., Mannan, A., Chaudhary, M.F. (2007). Effect of growth regulators and amino acids on artemisinin production in the callus of Artemisia absinthium. Pakistan Journal of Botany, 39, 799-805.

[65] Murashige, T., Skoog, F. (1962). A revised medium for rapid growth and bio assays with tobacco tissue cultures. Physiologia plantarum, 15, 473-497.

[66] Grech-Baran, M., Pietrosiuk, A. (2012). Artemisia species in vitro cultures for production of biologically active secondary metabolites. BioTechnologia, 93, 371-380.

[67] Bourgaud, F., Gravot, A., Milesi, S. (2001). Production of plant secondary metabolites: a historical perspective. Plant Science, 161, 839-851.

[68] Zhao, J., Davis, L.C., Verpoorte, R. (2005). Elicitor signal transduction leading to production of plant secondary metabolites. Biotechnology Advances, 23, 283-333.

[69] Zhong, J.J., Bai, Y., Wang, S.J. (1996). Effects of plant growth regulators on cell growth and ginsenoside saponin production by suspension cultures of Panax quinquefolium. Journal of Biotechnology, 45, 227-234.

[70] Okumuş, V., Pirinc, V., Onay, A. (2011). In vitro propagation of Diyarbakır watermelons and comparison of direct-seeded and transplanted watermelon. Turkish Journal of Biology, 35, 601-610.

[71] Verma, S.K., Yücesan, B.B., Gürel, S. (2011). Indirect somatic embryogenesis and shoot organogenesis from cotyledonary leaf segments of Digitalis lamarckii Ivan, an endemic medicinal species. Turkish Journal of Biology, 35, 743-750.

[72] Chaudhry, H., Fatima, N., Ahmad, I.Z. (2014). Establishment of callus and cell suspension cultures of nigella sativa 1 . For thymol production. International Journal of Pharmacy and Pharmaceutical Sciences, 6, 0975-1491.

[73] Hoseinpanahi, S., Majdi, M., Mirzaghaderi, G. (2016). Effects of growth regulators on in vitro callogenesis and regeneration of black cumin (Nigella sativa). Iranian Journal of Rangelands and Forests Plant Breeding and Genetic Research, 24(2), 242.

[74] Al-Ani, N.K. (2008). Thymol Production from Callus Culture of Nigella sativa L. Plant Tissue Culture \& Biotechnology, 18(2), 181-185.

[75] Chand, S., Roy, S. C. (1978). Effects of different auxins on callus tissues of Nigella sativa. Cell Chro, News Lett, 1, 10.

[76] Datta, A.K., Biswas, A.K., Ghosh, P. D. (1983). Chromosomal variations in callus tissues of two species of Nigella. Nucleus, 26, 173-177.

[77] Bibi, A., Khan, M.A., Adil, M., Mashwani, Z.U.R. (2018). Production of callus biomass and antioxidant secondary metabolites in black cumin. The Journal of Animal and Plant Sciences, 28(5).

[78] Gundlach, H., Müller, M.J., Kutchan, T.M. (1992). Jasmonic acid is a signal transducer in elicitor-induced plant cell cultures. Proceedings of the National Academy of Sciences USA, 89, 2389-2393.

[79] Mueller, M.J., Brodschelm, W., Spannagl, E. (1993). Signaling in the elicitation process is mediated through the octadecanoid pathway leading to jasmonic acid. Proceedings of the National Academy of Sciences USA, 90, 7490-7494. 
[80] Cai, G., Li, G., Ye, H. (1995). Hairy root culture of Artemisia annua L. by Ri plasmid transfdormation and biosynthesis of artemisinin. Chinese Journal of Biotechnology, 11, $227-235$.

[81] Liu, C.Z., Guo, C., Wang, Y. (2003). Factors influencing artemisinin production from shoot cultures of Artemisia annua L. World Journal of Microbiol Biotechnology, 19, 535-538.

[82] Ali, M., Kiani, B., Mannan, A. (2012). Enhanced production of artemisinin by hairy root cultures of Artemisia dubia. Journal of Medicinal Plant Research, 6, 1619-1622.

[83] Woerdenbag, H.J., Lüers, J.F.J., van-Uden, W. (1993). Production of the new antimalarial drug artemisinin in shoot cultures of Artemisia annua L. Plant Cell, Tissue and Organ Culture, 32, 247-257.

[84] Smith, T.C., Weathers, P.J., Cheetham, R.D. (1997). Effects of gibberellic acid on hairy root cultures of Artemisia annua: growth and artemisinin production. In Vitro Cellular and Developmental Biology- Plant, 33, 75-79.

[85] Paniego, N.B., Giulietti, A.M. (1996). Artemisinin production by Artemisia annua L.transformed organ cultures. Enzyme and Microbial Technology, 18, 526-530.

[86] Wang, H., Ye, H., Li, G. (1999). Effects of fungal elicitors on cell growth and artemisinin accumulation in hairy root cultures of Artemisia annua. Acta Botanica Sinica, 42, 905909.

[87] Youssef, A.A., Rady, M.R., Ghanem, S.A. (1998). Growth and some primary products in callus cultures of Nigella sativa as influenced by various cultural conditions and salt stress. Fitoterapia, LXIX, 4, 329-336.

[88] Khabir, E., Moradi, P.A. (2016). Study on impact of auxin and elicitors on tissue culture and proliferation of Nigella sativa L. 11(10), 1990-6145.

[89] Boselah, N.A.E. (1995). Seed germination of Nigella sativa L.

[90] Ibrahim, M.M., Arafa, M.N., Matter, M.A. (2015). Effect of some elicitors on chemicals composition for Nigella sativa callus cultures. World Journal of Pharmaceutical Sciences, 2015, 2321-3086.

[91]Ali, S.A., Solouki, M., Bahman, F.B. (2017). Optimization of Callus Induction and Effects of Biological and Nonbiological Elicitors on Content of Phenol/ Flavonoid Compounds in Nigella sativa under In-Vitro Conditions. Journal of Cell \& Tissue (JCT), 8(2), 165-184.

[92] Ali, M., Abbasi, B.H. (2014). Light-induced fluctuations in biomass accumulation, secondary metabolites production and antioxidant activity in cell suspension cultures of Artemisia absinthium L. Journal of Photochemistry and Photobiology B, 140, 223227.

[93] Abbasi, B.H., Tian, C.L., Murch, S.J. (2007). Light-enhanced caffeic acid derivatives biosynthesis in hairy root cultures of Echinacea purpurea. Plant Cell Reports, 26, 13671372.

[94] Georgieva, L., Ivanov, I., Marchev, A. (2015). Protopine production by Fumaria cell suspension cultures: effect of light. Applied Biochemistry and Biotechnology, 176, 287300 .

[95] Ahmad, N., Rab, A., Ahmad, N. (2015). Light-induced biochemical variations in secondary metabolites production and antioxidant activity in callus cultures of Stevia rebaudiana (Bert). Journal of Photochemistry and Photobiology B, 154, 51-56.

[96] Szopa, A., Ekiert, H., Szewczyk, A. (2012). Production of bioactive phenolic acids and furanocoumarins in in vitro cultures of Ruta graveolens L. and Ruta graveolens ssp. divaricata (Tenore) Gams under different light conditions. Plant Cell, Tissue and Organ Culture, 110, 329-336. 
[97] Chand, S., Roy, S. C. (1980a). Study of callus tissues from different parts of Nigella sativa (Ranunculaceae). Experientia, 36(3), 305-306. doi:10.1007/bf01952291

[98] Elhag, H., El-Olemy, M.M., Al-Said, M.S. (2004). Enhancement of somatic embryogenesis and production of developmentally arrested embryos in Nigella sativa L. Horticulture Science, 39, 321-323.

[99] Landa, P., Marsik, P., Vanek, T., Rada, V., Kokoska, L. (2006). In vitro anti-microbial activity of extracts from the callus cultures of some Nigella species. Biologia, 61(3). doi:10.2478/s11756-006-0052-6

[100] Srivastava, P., Sisodia, V., Chaturvedi, R. (2011). Effect of culture conditions on synthesis of triterpenoids in suspension cultures of Lantana camara L. Bioprocess and Biosystem Enginering, 34, 75-80.

[101] Moscatiello, R., Baldan, B., Navazio, L. (2013). Plant cell suspension cultures. Methods in Molecular Biology, 953, 77-93.

[102] Jalil, M., Annuar, M.S.M., Tan, B.C. (2015). Effects of selected physicochemical parameters on zerumbone production of Zingiber zerumbet Smith cell suspension culture. Evidence-Based Complementary and Alternative Medicine (eCAM), 2015, 757514.

[103] Li, H.H., Yao, D.H., Xu, J. (2015). Research on ursolic acid production of Eriobotrya japonica cell suspension culture in WAVE bioreactor. Zhongguo ZhongYao ZaZhi, 40, 1693-1698.

[104] Smith, J., Rogers, R., Jeon, S. (2015). Production of uniformly labeled ${ }^{13} \mathrm{C}$-Lutein and ${ }^{13} \mathrm{C}$ - $\alpha$-tocopherol in vitro using carrot cell suspension culture. FASEB Journal, 29, 604.

[105] Sahraroo, A., Mirjalili, M., Corchete, P. (2016). Establishment and characterization of a Satureja khuzistanica Jamzad (Lamiaceae) cell suspension culture: a new in vitro source of rosmarinic acid. Cytotechnology, 68, 1415-1424. doi.10.1007/s10616-0159901-x.

[106] Dong, Y., Duan, W., He, H. (2015). Enhancing taxane biosynthesis in cell suspension culture of Taxus chinensis by overexpressing the neutral/alkaline invertase gene. Process Biochemistry, 50, 651-660.

[107] Banerjee, S., Gupta, S. (1976). Embryogenesis and differentiation in Nigella sativa leaf callus in vitro. Physiologia Plantarum, 38, 115-120. doi: 10.1111/j.13993054.1976.tb04869.x

[108] ElNour, E.M., Mawahib, Mahmood, Z.A., Futooh, Yagoub, O., Sanaa. (2015). In Vitro Callus Induction and Antimicrobial Activities of Callus and Seeds Extracts of Nigella Sativa L. Research \& Reviews: Journal of Biology, 3(3), 21-28.

[109] Haroon, A., Qamar, S., Shireen, F. (2016). In vitro regenration protocol of nigella sativa using different plant growth regulators. International Conference on Forestry and Enviroment; Challenges and Prospects, University of Agriculture, Faisalabad, Pakistan, November, 138, 21-22.

[110] Scholz, M., Lipinski, M., Leupold, M., Luftmann, H., Harig, L., Ofir, R., Müller, K. J. (2009). Methyl jasmonate induced accumulation of kalopanaxsaponin I in Nigella sativa. Phytochemistry, 70(4), 517-522. doi:10.1016/j.phytochem.2009.01.018

[111] Ghosh, A., Gadgil, V.N. (1979). Shift in ploidy level of callus tissue: A function of growth subtances. Indian Journal of Experimental. Biology, 17, 562-564.

[112] Farag, M.A., El Sayed, A.M., El Banna, A., Ruehmann, S. (2015). Metabolomics reveals distinct methylation reaction in MeJA elicited Nigella sativa callus via UPLC-MS and chemometrics. Plant Cell, Tissue and Organ Culture (PCTOC), 122(2), 453-463.

[113] Banerjee, S., Gupta, S. (1975). Suspension culture of Nigella sativa. Cellular and Molecular Life Sciences, 31, 792-795. doi: 10.1007/BF01938469 
[114] Al-Salih, H.S. (2012). Evaluation of Deltamethrine Pesticide Effect in the Plant Cell Growth Using Nigella sativa L. Callus Cultures. Rafidain journal of science, 23(4A), 128136

[115] Haseeb, A., Elhag, H. inventor; Haseeb, A., Elhag, H., assignee. (2012). Process for producing melanin using cultures of the genus Nigella. WIPO patent, WO $2012125091 \mathrm{~A} 1$.

[116] Chand, S., Roy, S. C. (1980b). Cytological Abnormalities During Culture of Nigella sativa. Protoplasma, 104, 353-357.

[117] Chand, S., Roy, S.C. (1981). Induction of Organogenesis in Callus Cultures of Nigella sativa L. Annals of Botany, 48(1), 1-4. doi:10.1093/oxfordjournals.aob.a086087

[118] Sokmen, A., Jones, B. M., Erturk, M. (1999). Antimicrobial activity of extracts from the cell cultures of some Turkish medicinal plants. Phytotherapy Research, 13(4), 355-357. doi:10.1002/(sici)1099-1573(199906)13:4<355::aid ptr454>3.0.co;2-e

[119] Jha, T.B., Roy, S.C. (1979). Rhizogenesis From Nigella sativa Protoplasts. Protoplasma, 101, 139-142.

[120] Gany, Z.S.A., Mahdi, M.F. (2008). Cytotoxic Assay of Nigella sativa Leaf Callus Extract (Thymol) on Hep-2 Cell Line Using ELISA Assay. Iraqi Journal of Pharmaceutical Sciences, 17(2).

[121] Rasheed-uz-zafar., Kausar, A. (2013). Biotransformation of limonene by freely suspended and immobilised cells of Nigella sativa. International Journal of Pharmacy and Pharmaceutical Sciences, 5, 23-26.

[122] Mohammad, A.M.S., Jumma, N.E. (2006). Partial Purification of Glutamate Dehydrogenase from the Callus of Stems of (Nigella sativa L.) in the Presence of 2,4- D or PDA. Rafidain Journal of Science, 17, 80-93.

[123] AL-Noaimy, M.M., AL-Saleh, H.S. (2010). The Role of Interaction of some Growth Regulators with Salfanilamide on Initiation and Growth of Cell Suspension Culture of Black Seed Nigella sativa L. Rafidain Journal of Science, Journal of Mesopotamia, 21, 56-72.

[124] Al-Dulaimee, H.M., Abood, S.A. (2006). Presence of Dihydrofolate Reductase in Seedlings and Callus of Nigella Sativa L. Plant. Rafidain Journal of Science, Journal of Mesopotamia, 17, 26-38.

[125] Sobhanizadeh, A., Solouki, M., Fazeli-Nasab, B. (2017). Optimization of Callus Induction and Effects of Biological and Non- biological Elicitors on Content of Phenol/ Flavonoid Compounds in Nigella sativa under In-Vitro Conditions. Journal of Cell \& Tissue, 8(2), 165-184.

[126] Kumar, P.M., Vinmathi, V., Gautam, P., Wilson, A.H., Jacob, S.J.P. (2015). Green Synthesis of Silver Nanorods Using Aqueous Seed Extract of Nigella Sativa and Study of its Antidiabetic Activity. Australian Journal of Basic and Applied Sciences, 9(10), $295-$ 298.

[127] Amooaghaie, R., Saeri, M.R., Azizi, M. (2015). Synthesis, Characterization and Biocompatibility of silver nano-particles synthesized from Nigella sativa leaf extract in comparison with chemical silver nanoparticles. Ecotoxicology and Environmental Safety, 120, 400-408.

[128] Fragoon, A.L., Zhu, J., Zhao, J. (2012). Biosynthesis of Controllable Size and Shape Gold Nanoparticles by Black Seed (Nigella Sativa) Extract. Journal of Nanoscience and Nanotechnology, 12(3), 2337-2345.

[129] Sangeetha, J., Sandhya, J., Philip, J. (2014). Biosynthesis and Functionalization of Silver Nanoparticles Using Nigella sativa, Dioscorea alata and Ferula asafetida. Science of Advanced Materials, 6(8), 1681-1690. 
[130] Ravindran, J., Nair, H.B., Sung, B., Prasad, S., Tekmal, R.R., Aggarwal, B.B. (2010). Thymoquinone Poly (lactideco-glycolide) Nanoparticles Exhibit Enhanced Antiproliferative, Anti-inflammatory and Chemosensitization Potential. Biochemical Pharmacology, 79(11), 1640-1647.

[131] Manju, S., Malaikozhundan, B., Chen, J.C., Vaseeharan, B. (2014). Essential Oil of Nigella Sativa Based Synthesis of Silver Nanoparticles and Its Effect on Pathogenic Vibrio Harveyi and Vibrio Parahaemolyticus isolated from Aquatic Environments. Journal of The Fisheries Society of Taiwan, 41(2), 123- 134.

[132] Gilani, A.U.H., Jabeen, Q., Khan, M.A.U. (2004). Pakistan Journal of Biological Sciences, 7, 441-451.

[133] Alemi, M., Sabouni, F., Sanjarian, F., Haghbeen, K., Ansari, S. (2013). Antiinflammatory effect of seeds and callus of Nigella sativa L. extracts on mix glial cells with regard to their thymoquinone content. AAPS PharmSciTechn, 14, 160-167.

[134] Yang, L., Stöckigt, J. (2010). Trends for diverse production strategies of plant medicinal alkaloids. Natural product reports, 27(10), 1469-1479.

[135] Yue, W., Ming, Q.L., Lin, B., Rahman, K., Zheng, C.J., Han, T., Qin, L.P. (2016). Medicinal plant cell suspension cultures: pharmaceutical applications and high-yielding strategies for the desired secondary metabolites. Critical reviews in biotechnology, 36(2), 215-232.

[136] Ferrari, S. (2010). Biological elicitors of plant secondary metabolites: Mode of action and use in the production of nutraceutics. Bio-Farms for Nutraceuticals, 152-166.

[137] Zhang, B., Zheng, L.P., Wang, J.W. (2012). Nitric oxide elicitation for secondary metabolite production in cultured plant cells. Applied microbiology and biotechnology, 93(2), 455-466.

[138] Zhao, J., Davis, L.C., Verpoorte, R. (2005). Elicitor signal transduction leading to production of plant secondary metabolites. Biotechnology advances, 23(4), 283-333.

[139] Ramirez-estrada, K., Vidal-limon, H., Hidalgo, D., Moyano, E., Golenioswki, M., Cusido, R.M. (2016). Elicitation, an Effective Strategy for the Biotechnological Production of Bioactive High-Added Value Compounds in Plant Cell Factories. Molecules, 21(2), 182.

[140] Golkar, P., Moradi, M., Garousi, G.A. (2018). Elicitation of Stevia glycosides using salicylic acid and silver nanoparticles under callus culture. Sugar Tech. 3, 1-9.

[141] Tahmasi, S., Garoosi, G., Ahmadi, J., Farjaminezhad, R. (2017). Effect of salicylic acid on stevioside and rebaudioside A production and transcription of biosynthetic genes in in vitro culture of Stevia rebaudiana. Iranian Journal of genetics and plant breeding, 6(2), $1-8$.

[142] Lucho, S.R., Do-amaral, M.N., Milech, C., Ferrer, M.Á., Calderón, A.A., Bianchi, V.J., Braga, E.J.B. (2018). Elicitor-Induced Transcriptional Changes of Genes of the Steviol Glycoside Biosynthesis Pathway in Stevia rebaudiana Bertoni. Journal of Plant Growth Regulation, 37(3), 971-985.

[143] Bayraktar, M., Naziri, E., Karabey, F., Akgun, I., Bedir, E., Röck-okuyucu, B., Gürel, A. (2018). Enhancement of stevioside production by using biotechnological approach in in vitro culture of Stevia rebaudiana. International Journal of Secondary Metabolite, 5 (4), 362-374. 